\title{
PENGARUH INFLASI, BIAYA OPERASIONAL TERHADAP PENDAPATAN OPERASIONAL (BOPO), DAN PANGSA PASAR TERHADAP PROFITABILITAS BANK UMUM SYARIAH DI INDONESIA PRIODE 2012-2018
}

\author{
Nanda Suryadi $^{1}$, Riri Mayliza ${ }^{2}$ \& Ismail Ritonga ${ }^{3}$ \\ ${ }^{1}$ Fakultas Ekonomi dan Ilmu Sosial, Unversitas Islam Negeri SUSKA RIAU \\ ${ }^{2}$ Sekolah Tinggi Ilmu Ekonomi (STIE) KBP Padang \\ ${ }^{3}$ Fakultas Ekonomi dan Ilmu Sosial, Universitas Islam Negeri SUSKA RIAU \\ Email:nanda_suryadi@yahoo.com,ririmayliza6@gmail.com, \\ ismail_ritonga@yahoo,com
}

\begin{abstract}
ABSTRAK
Penelitian ini dilakukan untuk menguji pengaruh inflasi yang diukur dengan pertumbuhan inflasi, Biaya operasional terhadap pendapatan operasional (BOPO), dan pangsa pasar yang diukur dengan pangsa pembiayaan terhadap Return On Asset (ROA) Bank Syariah di Indonesia. Data yang digunakan dalam penelitian ini diperoleh dari laporan keuangan publikasi Bank Indonesia, serta laporan publiksai bank syariah melalui website. Teknik sampling yang digunakan adalah purposive sampling. Sampel dalam penelitian ini adalah 9 bank syariah. Teknik analisis data yang digunakan dalam penelitian ini adalah analisis regresi linier berganda dimana sebelumnya data telah diuji dengan pengujian asumsi klasik meliputi normalitas data, heteroskedastisitas, multi kolinieritas dan auto korelasi. Selama periode pangamatan menunjukan bahwa data penelitian berdistribusi normal. Berdasarkan uji normalitas, uji multi kolinearitas, uji heteros kedastisitas, dan uji auto korelasi tidak ditemukan variabel yang menyimpang dari asumsi klasik. Hal ini menunjukkan data yang tersedia telah memenuhi syarat menggunakan model persamaan regresi linier berganda. Hasil penelitian ini menunjukkan bahwa variabel inflasi dan pangsa pasar tidak menunjukkan pengaruh signifikan terhadap ROA. Variabel BOPO berpengaruh positif dan signifikan terhadap ROA. Kemampuan prediksi dari ketiga variabel tersebut terhadap ROA dalam penelitian ini sebesar $93.9 \%$ sedangkan sisanya dipengaruhi faktor lain yang tidak dimasukkan ke dalam model penelitian.
\end{abstract}

Kata kunci : Inflasi, BOPO, Pangsa Pasar, Profitabilitas.

\begin{abstract}
This study aimed to examine the effect of inflation based on inflation growth, operational cost and operating income (BOPO), and market share. The market share was measured by calculating the share of financing for return on assets (ROA) from Sharia banks in Indonesia. The data were collected from the publication of the Bank Indonesia Financial Reports and Financial Statements of sharia banks inputted on their websites. The sampling technique used a purposive sampling that took from 9 Sharia banks. The data were then analyzed using multiple linear regression analyses which were initially examined through classic assumption testing. The test included data normality, heteroscedasticity, multicollinearity, and autocorrelation. The researcher found that the data were normally distributed. According to the normality of the multicollinearity test, heteroscedasticity test, and autocorrelation test, no variables were deviating from the classical assumptions. It indicated that the data met the requirements to use the multiple linear regression equation models. The results of this study conclude that inflation and market share do not have a significant effect on ROA. BOPO variables affect positively and significantly $R O A$. The predictive ability of the three variables on ROA is $93.9 \%$, while the rest is influenced by other factors not included in the research model.
\end{abstract}

Keywords : Inflation, BOPO, Market Share, Profitability. 


\section{PENDAHULUAN}

Laporan keuangan adalah laporan yang disajikan oleh sebuah lembaga baik bank maupun non bank yang bersumber dari fakta-fakta dan transaksi-transaksi yang dilakukan perusahaan. Ini bertujuan untuk memberi informasi kepada pihak lain maupun kepada perusahaan itu sendiri guna meningkatkan kinerja perusahaan yang lebih optimal dan maksimal dalam mencapai tujuan perusahaan itu sendiri.

$\begin{array}{ccc}\text { Bank } & \begin{array}{c}\text { merupakan } \\ \text { keuangan }\end{array} & \begin{array}{c}\text { lembaga } \\ \text { (financial }\end{array}\end{array}$
intermediaries) yang menyalurkan dana dari pihak kelebihan dana (surplus unit) kepada pihak yang membutuhkan dana (defisit unit) pada waktu yang ditentukan. Di dalam Undang-Undang No. 7 Tahun 1992 Tentang Perbankan sebagaimana telah diubah dengan Undang-Undang No. 10 Tahun 1998 disebutkan bahwa Bank adalah badan usaha yang menghimpun dana dari masyarakat dalam bentuk simpanan dan menyalurkannya kepada masyarakat dalam bentuk kredit dan atau bentukbentuk lainnya dalam rangka meningkatkan taraf hidup rakyat banyak.

Perkembangan industri perbankan syariah pada tahun 2017 masih minim. Ini terlihat dari total asset perbankan syariah yang masih berada di kisaran $4,63 \%$ pada kuartal I 2015 dan meningkat menjadi 5,33\% di 2017 dari total asset perbankan nasional. Kondisi ini tidak lepas dari pertumbuhan dana pihak ketiga (DPK) perbankan syariah yang melambat dalam beberapa tahun terakhir. Akibatnya pembiayaaan perbankan syariah mengalami perlambatan, jika dibandingkan dengan negara tetangga total asset mencapai $21,3 \%$.

Menurut sumber dari detikfinance.com menyebutkan bahwa alasan mengapa perbankan syariah masih sangat lesu adalah perbankan syariah hanya memfokuskan pada fungsi sebagai bank komersial namun tidak memaksimalkan fungsi sebagai bank investasi, disisi lain bank syariah cendrung tertuju pada penyaluran kredit jangka pendek seperti kredit usaha rakyat, kemudian produk yang dikembangkan bank syariah juga sangat tebatas misalnya wadiah (titipan), mudharabah (pinjaman), musyarakah. Jika dilihat pangsa pasar syariah di luar negeri seperti Saudi Arabia dengan persentase sebesar 51,2\%, Kuwait sebesar 45,2\%, Bahrain sebesar 29,3\%, Qatar sebesar 25,8\%, Malaysia sebesar 21,3\%, Uni Emirat Arab sebesar 21,3\%, Pakistan sebesar 10,4\%, dan Turki sebesar 5,5\%, sedangkan Indonesia berada di urutan belakang dengan besaran 5,33\%, kondisi jauh dari harapan karena mengingat Indonesia adalah Negara dengan mayoritas penduduk Muslim terbesar di dunia namun hanya bisa memperoleh market share sebesar $5,33 \%$. Harus diakui bahwa perkembangan perbankan syariah di indonesia masih kecil.

Penulis menemukan beberapa penelitian terdahulu yang membahas topik yang sama dengan penelitian ini. Penelitian yang dilakukan oleh Agung Gumelar (2016) tentang pengaruh inflasi, suku bunga, kurs, NPF, BOPO, terhadap profitabilitas bank umum syariah menunjukkan bahwa inflasi, suku bunga, nilai tukar dan NPF tidak berpengaruh secara signifikan terhadap ROA. BOPO berpengaruh terhadap profitabilitas, sementara dalam penelitian Sahara (2013) bertentangan dengan hasil yang didapat oleh Agung Gumelar dimana analisis pengaruh inflasi, suku bunga BI, dan PDB terhadap profitabilitas bank syariah menunjukkan bahwa, inflasi dan PDB berpengaruh positif terhadap ROA begitu juga dengan 
suku bunga berpengaruh negatif terhadap ROA.

\section{TINJAUAN PUSTAKA \\ Inflasi}

Inflasi merupakan salah satu bentuk penyakit ekonomi yang sering kambuh dan dialami oleh hampir semua Negara. Langkah untuk memerangi inflasi merupakan salah satu fokus dan kebijakan ekonomi. Kebijakan yang berkaitan dengan inflasi biasanya dikenal sebagai kebijakan stabilitas harga atau kebijakan untuk mencapai keseimbangan interen. Defenisi sederhana mengenai inflasi menyatakan bahwa inflasi merupakan kecendrungan kenaikan harga-harga. Inflasi (inflation) merupakan kenaikan harga barang dan jasa, yang terjadi jika pembelanjaan bertambah dibandingkan dengan penawaran barang di pasar, dengan kata lain terlalu banyak uang yang memburu barang yang terlalu sedikit.

Inflasi di definisikan sebagai kecenderungan kenaikan harga secara umum. Kecenderungan yang dimaksudkan disini adalah bahwa kenaikan tersebut bukan terjadi sesaat. Misalnya, harga-harga barang menjelang lebaran, atau hari libur lainnya, cenderung naik. Namun, setelah perayaan usai, masyarakat kembali hidup seperti semula, harga akan kembali ke kondisi semula (Djohanputro, 2006) singkatnya inflasi adalah gejala kenaikan barang-barang yang bersifat umum dan terus-menerus (Rahardja \& Manurung, 2008)

\section{Biaya Operasional terhadap}

\section{Pendapatan Operasional (BOPO)}

BOPO adalah perbandingan antara biaya operasional dan pendapatan operasional. Semakin rendah tingkat rasio BOPO maka semakin baik kinerja manajemen bank karena lebih efisien dalam menggunakan sumber daya (Riyadi dalam Nadiroh, 2016)

BOPO adalah perbandingan antara Biaya Operasional dengan Pendapatan Operasional yang diperoleh (Dendawijaya, 2010) BOPO dapat diukur menggunakan rumus sebagai berikut:

$$
\begin{gathered}
\mathrm{BOPO}=\frac{\text { biaya operasional }}{\text { pendapatan operasional }} \\
100 \%
\end{gathered}
$$

\section{Pangsa Pasar}

Pangsa pasar adalah porsi dari penjualan industri dari barang atau jasa dikendalikan oleh perusahaan. Analisis pangsa pasar mencerminkan kinerja pemasaran yang dikaitkan dengan posisi persaingan perusahaan dalam suatu industri. Ada dua teori besar mengenai pangsa pasar yaitu SCP (structure conduct performance) dan teori efisiensi. Teori SCP merupakan suatu model untuk menghubungkan antara struktur pasar suatu industri dengan prilaku perusahaan serta kinerjanya. Sedangkan teori efisiensi merupakan suatu model yang menjelaskan bagaimana efisiensi operasional suatu perusahaan mampu mempengaruhi kinerja perusahaan serta pangsa pasarnya.

Mahzab teori alternatifnya adalah Relatif Effeciency (RE). Aliran ini bertentangan dengan asumsi SCP, dimana diyakini bahwa efisiensi perusahaan dapat mengakibatkan marjin (kinerja) yang tinggi, sehingga pada akhirnya dapat meningkatkan pangsa pasarnya. Dengan demikian, struktur pasar tidak selalu mempengaruhi kinerja. Aliran RE mengkhawatirkan bahwa pengaturan yang terlalu ketat terhadap struktur pasar pasar (seperti yang direkomendasikan aliran SCP) justru akan mempengaruhi insentif perusahaan untuk meningkatkan efisiensinya. (Arianto, 2004) 


\section{Profitabilitas (ROA)}

Return on Assets (ROA) yang merupakan salah satu rasio profitabilitas. ROA dihitung dari laba sebelum pajak dibagi total aset. Laba sebelum pajak adalah laba bersih dari kegiatan operasional bank sebelum pajak. Total aset yang digunakan untuk mengukur ROA adalah jumlah keseluruhan dari aset yang dimiliki oleh bank yang bersangkutan ROA dihitung dengan menggunakan rumus:

$\mathrm{ROA}=\frac{\text { laba sebelum pajak }}{\text { total aset }} \times 100 \%$

\section{METODE PENELITIAN}

Penelitian ini termasuk dalam penelitian kuantitatif. Penelitian dilakukan dimulai dari pengumpulan data yang berhubungan langsung dengan objek penelitian, mengolah data hingga akhirnya diperoleh gambaran yang jelas tentang pokok permasalahan yang diteliti. Penelitian ini dilakukan sesuai dengan keadaan perekonomian Indonesia. Melihat perbankan syariah sebagai suatu lembaga yang bertahan dari krisis keuangan tahun 1998, lalu juga melihat dari faktor-faktor lain yang mempengaruhi perbankan syariah.

Ruang lingkup penelitian ini adalah melihat pengaruh inflasi, BOPO, dan pangsa pasar, terhadap profitabilitas bank umum syariah di indonesia periode 2012-2018. Data yang diambil merupakan data setiap akhir semester setelah data di publikasikan. Sedangkan jenis data yang penullis gunakan pada penelitian ini adalah data data runtun (time series).

\section{Populasi dan Sampel}

Populasi dalam hal ini adalah seluruh bank syariah yang terdaftar di bank Indonesia periode 2012-2018, sedangkan sampel adalah bagian dari karateristik yang dimiliki oleh populasi. Pengambilan sampel dilakukan dengan purposive sampling, yaitu pengambilan sampel berdasarkan karakteristik yang dianggap mempunyai hubungan dengan karakteristik populasi yang sudah diketahui sebelumnya.

Tabel 1. Pengambilan Sampel Penelitian

\begin{tabular}{lc}
\hline \multicolumn{1}{c}{ Keterangan } & Jumlah Bank \\
\hline $\begin{array}{l}\text { Jumlah bank umum syariah yang } \\
\text { ada di Indonesia }\end{array}$ & 11 \\
\hline $\begin{array}{l}\text { Bank umum syariah yang nilai } \\
\text { BOPO nya negatif }\end{array}$ & 2 \\
\hline $\begin{array}{l}\text { Jumlah bank umum syariah yang } \\
\text { memenuhi kriteria penelitian }\end{array}$ & 9 \\
\hline
\end{tabular}

Sumber: www.bi.go.id (2018)

\section{HASIL DAN PEMBAHASAN Statistik Deskriptif}

Statistik deskriptif memberikan gambaran atas deskripsi suatu data yang dilihat dari nilai rata-rata (mean), standar deviasi, maksimum dan minimum. Hasil analisis statistik deskripsi dalam penelitian ini dapat dilihat dalam tabel 2 di bawah ini : 
2020, Jurnal Tabarru' : Islamic Banking and Finance 3 (1) : 01 - 10

Tabel 2. Statistik Deskriptif Variabel Penelitian

Descriptive Statistics

\begin{tabular}{|c|c|c|c|c|c|c|}
\hline & $\mathrm{N}$ & & Minimum & Maximum & Mean & Std. Deviation \\
\hline INFLASI & & 54 & 3.02 & 8.38 & 5.1700 & 2.31668 \\
\hline BOPO & & 54 & 47.60 & 217.40 & 93.7693 & 19.33043 \\
\hline PP & & 54 & .01 & 4.10 & 2.1499 & 1.14283 \\
\hline PROFITABILITAS & & 54 & -10.77 & 3.81 & .7243 & 1.81158 \\
\hline Valid N (listwise) & & 54 & & & & \\
\hline
\end{tabular}

Sumber: Data Olahan SPSS (2019)

Tabel 2 diatas menggambarkan deskripsi variabel-variabel yang digunakan dalam penelitian ini. Minimum adalah nilai terkecil dari suatu rangkaian pengamatan, maksimum adalah nilai terbesar dari suatu rangkaian pengamatan, mean (rata-rata) adalah hasil penjumlahan nilai seluruh data dibagi dengan banyaknya data, sementara standar deviasi adalah akar dari jumlah kuadrat dari selisih nilai data dengan rata-rata dibagi dengan banyaknya data.

\section{Uji Normalitas Data}

Uji normalitas digunakan untuk menguji apakah dalam model regresi variabel independen dan variabel dependen berdistribusi normal atau mendekati normal. Cara untuk mendeteksi apakah residual berdistribusi normal atau tidak yaitu dengan menggunakan analisis grafik (Normal $P$ $P$ Plot) dan analisis statistik (One Sample Kolmogorov Smirnov), dengan hasil analisis sebagai berikut

\section{Tabel 3. Hasil One-Sample Kolmogorov-Smirnov}

\section{One-Sample Kolmogorov-Smirnov Test}

\begin{tabular}{llr}
\hline $\mathrm{N}$ & & \multicolumn{2}{c}{$\begin{array}{c}\text { Unstandardized } \\
\text { Residual }\end{array}$} \\
\hline Normal Parameters ${ }^{\mathrm{a}, \mathrm{b}}$ & Mean & 54 \\
& Std. Deviation & .0000000 \\
& Absolute & .43526598 \\
Most Extreme Differences & Positive & .169 \\
& Negative & .169 \\
Kolmogorov-Smirnov Z & & -.157 \\
Asymp. Sig. (2-tailed) & & 1.242 \\
\hline
\end{tabular}
a. Test distribution is Normal.
b. Calculated from data.

Sumber : Data Olahan SPSS (2019)

Berdasarkan tabel 3 diatas dapat kita lihat bahwa ke tiga variabel tersebut
K-S-Z dengan $\mathrm{P}>0$ 0,05. Maka dengan demikian dapat kita simpulkan bahwa 
semua variabel telah terdistribusi dengan normal. Selanjutnya dapat dilakukan uji asumsi klasik.

\section{Uji Multikolinearitas}

Uji Multikolinearitas digunakan untuk mengetahui ada atau tidaknya hubungan linear antara variabel independen dalam model regresi. Salah satu cara untuk mengetahui ada tidaknya multikolinearitas pada suatu model regresi adalah dengan melihat nilai tolerance dan VIF (Variance Inflation Factor). Jika nilai tolerance $>0,1$ dan VIF $<10$, maka dapat diartikan bahwa tidak terdapat multikolinearitas pada penelitian tersebut. Hasil uji multikolinearitas dapat dilihat dari tabel berikut:

Tabel 4. Hasil Uji Multikolinieritas

Coefficients $^{\mathrm{a}}$

\begin{tabular}{|c|c|c|c|c|c|c|c|c|}
\hline \multirow[t]{2}{*}{ Model } & \multicolumn{3}{|c|}{ Unstandardized Coefficients } & \multicolumn{2}{|c|}{$\begin{array}{l}\text { Standardized } \\
\text { Coefficients }\end{array}$} & \multicolumn{3}{|c|}{ Collinearity Statistics } \\
\hline & $\mathrm{B}$ & & Std. Error & Beta & & Tolerance & VIF & \\
\hline (Constant) & & 9.343 & .370 & & & & & \\
\hline INFLASI & & -.017 & .027 & & -.021 & .985 & & 1.016 \\
\hline BOPO & & -.091 & .003 & & -.973 & .988 & & 1.013 \\
\hline PP & & .008 & .054 & & .005 & .997 & & 1.003 \\
\hline
\end{tabular}

a. Dependent Variable: PROFITABILITAS

Sumber: Data Olahan SPSS (2019)

Dari tabel 4 diatas dapat dilihat bahwa nilai variance inflation factor (VIF) dari model analisis pada penelitian ini berada di bawah angka 10, yaitu inflasi $\left(\mathrm{X}_{1}\right)$ memiliki VIF sebesar 1.016, BOPO $\left(\mathrm{X}_{2}\right)$ memiliki VIF sebesar 1.013 dan pangsa pasar $\left(\mathrm{X}_{3}\right)$ memiliki VIF sebesar 1.003. nilai tolerance $>0.1$ yaitu inflasi memiliki tolerance sebesar 0.985 , BOPO memiliki tolerance sebesar 0.988 , dan pangsa pasar memiliki tolerance sebesar 0.997. Dari ketentuan yang telah disebutkan dia atas, telah diketahui nilai VIF dan tolerance masing-masing variable dalam penelitian ini tidak terjadi multikolinieritas dalam model regresinya. Multikolinieritas digunakan untuk mengetahui ada atau tidaknya hubungan linier antara variabel independen dalam model regresi.

\section{Uji Autokorelasi}

Uji autokorelasi bertujuan untuk menguji apakah dalam suatu model regresi linear ada korelasi antara kesalahan pengganggu pada periode $\mathrm{t}-1$ (sebelumnya). Jika terjadi korelasi, berarti terdapat autocorrelation.

\section{Tabel 5. Durbin-Waston Test}

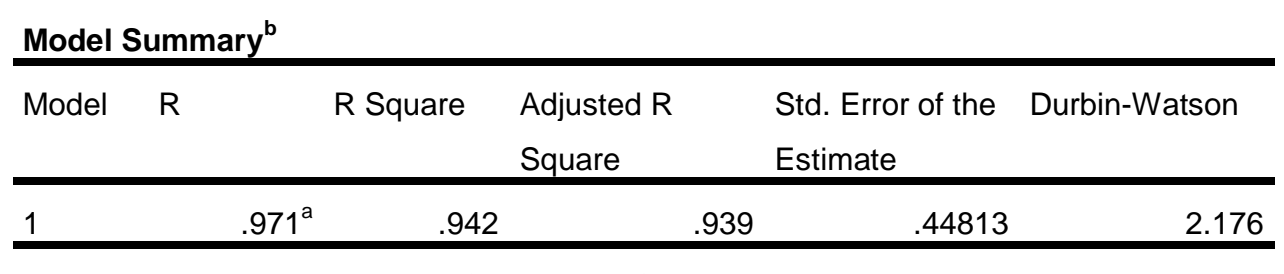

a. Predictors: (Constant), PP, BOPO, INFLASI 
b. Dependent Variable: PROFITABILITAS

Sumber : Data Olahan SPSS (2019)

Pada tabel 5 diatas menunjukkan bahwa nilai statistic Durbin-waston sebesar 2.176. Angka ini menunjukkan bahwa nilai D-W diatas 2, maka dapat disimpulkan bahwa ada autokorelasi negatif antar residual.

\section{Pengujian Hipotesis Variabel Secara Parsial (T-Test)}

Pengujian variable secara parsial dilakukan untuk mengetahui apakah masing-masing variabel independen (Inflasi ,BOPO, Pangsa Pasar) mempunyai pengaruh terhadap variabel dependen (Profitabilitas).

Tabel 6. Hasil Uji Hipotesis Parsial

Coefficients $^{a}$

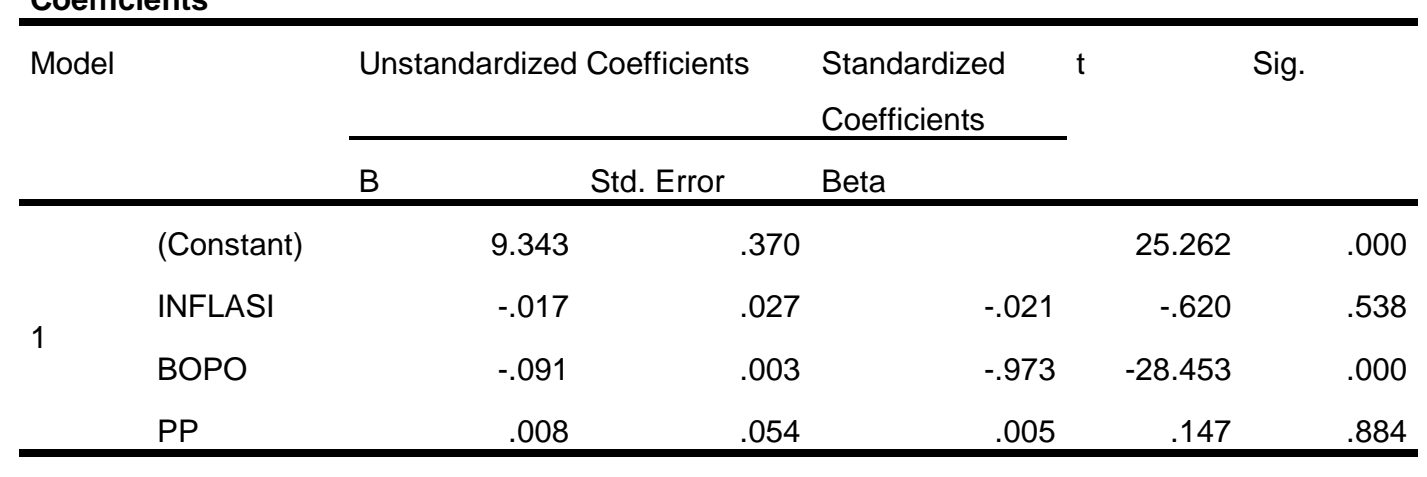

a. Dependent Variable: PROFITABILITAS

Sumber: Data Olahan SPSS (2019)

Berdasarkan dari tabel diatas, dapat dilihat bahwa nilai signifikan uji $\mathrm{T}$ untuk :

1. Hipotesis pertama yang diajukan dalam penelitian ini adalah untuk menguji bagaimana pengaruh inflasi terhadap profitabilitas (ROA). Dari hasil SPSS pada tabel 6 diatas diketahui nilai $t_{\text {hitung }}$ sebesar -0.620 , sedangkan $t_{\text {tabel }}$ 2.008 , dimana $t_{\text {hitung }}-0.620<t_{\text {tabel }}$ 2.008, dengan tingkat signifikan sebesar 0.538 berada lebih tinggi pada $\alpha=0.05$. maka hipotesis pertama yang menyatakan bahwa inflasi berpengaruh signifikan terhadap profitabilitas (ROA) ditolak artinya bahwa inflasi tidak berpengaruh terhadap profitabilitas (ROA).
2. Hipotesis kedua yang diajukan dalam penelitian ini adalah untuk menguji bagaimana pengaruh BOPO terhadap profitabilitas (ROA). Dari hasil SPSS pada tabel 6 diatas diketahui nilai $\mathrm{t}_{\text {hitung }}$ sebesar -28.453, sedangkan $t_{\text {tabel }}$ 2.008 , dimana $\mathrm{t}_{\text {hitung }}-28.453<\mathrm{t}_{\text {tabel }}$ 2.008, dengan tingkat signifikan sebesar 0.000 berada lebih rendah pada $\alpha=0.05$. maka hipotesis kedua yang menyatakan bahwa BOPO berpengaruh signifikan terhadap profitabilitas (ROA) diterima artinya bahwa BOPO berpengaruh terhadap profitabilitas (ROA).

3. Hipotesis ketiga yang diajukan dalam penelitian ini adalah untuk menguji bagaimana pengaruh Pangsa Pasar terhadap 
profitabilitas (ROA). Dari hasil SPSS pada tabel 6 diatas diketahui nilai $\mathrm{t}_{\text {hitung }}$ sebesar 0.147 , sedangkan $\mathrm{t}_{\text {tabel }} 2.008$, dimana $\mathrm{t}_{\text {hitung }} 0.147<\mathrm{t}_{\text {tabel }} 2.008$, dengan tingkat signifikan sebesar 0.884 berada lebih tinggi pada $\alpha$ $=0.05$. maka hipotesis ketiga yang menyatakan bahwa Pangsa Pasar berpengaruh signifikan terhadap profitabilitas (ROA) ditolak. Artinya bahwa Pangsa Pasar tidak berpengaruh terhadap profitabilitas (ROA).

\section{Pengujian Variabel Secara Simultan} (F-Test)

Uji secara simultan (F-Test) pada dasarnya menunjukkan apakah semua variabel independen yang dimaksud dalam penelitian ini mempunyai pengaruh secara simultan (bersamasama) terhadap variabel dependen (Ghozali, 2006). Dari hasil pengujian F dapat dilihat hasil yang diperoleh dari tabel 7 sebagai berikut:

Tabel 7. Hasil Uji Hipotesis Simultan

\begin{tabular}{rlrrrrr}
\hline ANOVA $^{\mathrm{a}}$ & & & & & & \\
\hline Model & Sum of Squares & Df & & Mean Square & $F$ & \multicolumn{2}{c}{ Sig. } \\
\hline \multirow{4}{*}{1} & Regression & 163.895 & 3 & 54.632 & 272.038 & $.000^{\mathrm{b}}$ \\
& Residual & 10.041 & 50 & .201 & & \\
& Total & 173.936 & 53 & & & \\
\hline
\end{tabular}

a. Dependent Variable: PROFITABILITAS

b. Predictors: (Constant), PP, BOPO, INFLASI

\section{Sumber : Data Olahan SPSS (2019)}

Berdasarkan hasil perhitungan diperoleh nilai $f$ test (f hitung) sebesar 272.038 dengan tingkat signifikasi sebesar 0,000 (di bawah 0,05) atau $t_{\text {hitung }}$ $=272.038$ lebih besar dari dari $\mathrm{t}_{\text {tabel }}=$ 2,008. Memperhatikan hasil uji test ini, maka hipotesis keempat menyatakan bahwa inflasi, BOPO, Pangsa Pasar berpengaruh terhadap profitabilitas, karena inflasi, BOPO, dan Pangsa Pasar memberikan kontribusi signifikan terhadap Profitabilitas (ROA).

\section{Analisis Regresi Linier Berganda}

Persamaan regresi dapat dilihat dari tabel hasil uji coeficients berdasarkan output SPSS versi 21 terhadap ke 3 variabel independen yaitu Inflasi, BOPO, dan Pangsa Pasar terhadap profitabilitas (ROA) ditunjukkan pada tabel 8 berikut ini : 
2020, Jurnal Tabarru' : Islamic Banking and Finance 3 (1) : 01 - 10

Table 8. Hasil Perhitungan Regresi

\begin{tabular}{lllll}
\multicolumn{1}{l}{ Coefficients $^{\mathrm{a}}$ Model } & \multicolumn{3}{l}{ Unstandardized Coefficients } & \multicolumn{2}{l}{$\begin{array}{l}\text { Standardized } \\
\text { Coefficients }\end{array}$} \\
\cline { 3 - 6 } & & \multicolumn{4}{c}{ Std. Error } & Beta \\
\hline & (Constant) & 9.343 & .370 & \\
1 & INFLASI & -.017 & .027 & -.021 \\
& BOPO & -.091 & .003 & -.973 \\
& PP & .008 & .054 & .005 \\
\hline
\end{tabular}

a. Dependent Variable: PROFITABILITAS

Sumber : Data Olahan SPSS (2019)

Pada tabel 8 di interprestasikan adalah nilai dalam kolom $\mathrm{B}$, baris pertama menunjukkan konstanta (a) dan baris selanjutnya menunjukkan variabel independen. Dengan melihat tabel diatas dapat disusun persamaan regresi linier berganda sebagai berikut: $\mathrm{ROA}=9.343$ 0.017 INFLASI - 0.091BOPO - 0.008 PANGSA PASAR

Persamaan regresi terebut dapat dijelaskan sebagai berikut :

1. Konstanta sebesar 9.343 artinya menyatakan bahwa jika variabel independen tetap maka variabel dependen adalah sebesar 9.343.

2. Koefisien regresi variabel inflasi sebesar -0.017 artinya jika variabel independen lain nilainya tetap dan inflasi mengalami kenaikan $1 \%$ maka profitabilitas akan mengalami penuruan sebesar 0.017. koefisien bernilai negatif artinya terjadi hubungan negatif antara inflasi dengan profitabilitas (ROA).

3. Koefisien regresi variabel BOPO sebesar -0.91 artinya jika variabel independen lain nilainya tetap dan BOPO mengalami kenaikan $1 \%$ maka profitabilitas akan mengalami penurunan sebesar 0.091. koefisien bernilai negatif artinya terjadi hubungan negatif antara BOPO dengan profitabilitas (ROA).

4. Koefisien regresi variabel pangsa pasar sebesar -0.008 artinya jika variabel independen lain nilainya tetap dan pangsa pasar mengalami kenaikan 1\% maka profitabilitas akan mengalami penuruan sebesar 0.008 . koefisien bernilai negatif artinya terjadi hubungan negatif antara pangsa pasar dengan profitabilitas (ROA).

\section{KESIMPULAN}

Berdasarkan pengolahan data dan hasil analisis data yang mengacu pada masalah dan tujuan penelitian, maka dapat dirumuskan kesimpulan penelitian sebagai berikut:

1. Dari hasil SPSS pada tabel 6 diatas menunjukkan bahwa inflasi tidak berpengaruh signifikan terhadap profitabilitas (ROA), secara kajian teori maka hasil penelitian pada perbankan Syariah di Indonesia cenderung lebih sesuai dengan Teori Ekonomi Islam murni yang menjelaskan bahwa pada ekonomi Islam lebih 
mengutamakan perputaran uang pada sektor riil sehingga ada kesesuaian antara money supply dan money demand. Dalam Islam tidak mengenal uang sebagai bentuk investasi melainkan hanya sebagai alat tukar, sehinga uang harus diputar untuk usaha riil yang mendatangkan manfaat.

2. Dari hasil SPSS pada tabel 6 diatas menunjukkan bahwa BOPO berpengaruh terhadap profitabilitas. Penelitian ini menunjukkan semakin tinggi tingkat biaya operasional maka akan menunrunkan profit dari perbankan Syariah itu sendiri.

3. Dari hasil SPSS pada tabel 6 diatas menunjukkan bahwa pangsa pasar tidak berpengaruh signifikan terhadap profitabilitas (ROA). Pangsa pasar yang meningkat dengan kenaikan penjualan yang kemungkinan tidak diikuti oleh tingkat produktivitas akan mempengaruhi naik turunnya laba perusahaan. Sehingga pangsa pasar menjadi tidak berpengaruh terhadap profitabilitas.

4. Berdasarkan hasil perhitungan diperoleh maka hipotesis keempat menyatakan bahwa inflasi, BOPO, pangsa pasar berpengaruh terhadap profitabilitas, karena inflasi, BOPO, dan pangsa pasar memberikan kontribusi signifikan terhadap profitabilitas (ROA).

\section{DAFTAR PUSTAKA}

Agung Gumelar, Heri. 2016. Pengaruh Inflasi, Suku Bunga, Kurs, Non Performing Financing (NPF) dan Biaya Operasional terhadap Pendapatan Operasional (BOPO) terhadap Tingkat
Profitabilitas Bank Umum Syariah Periode 2011-2014. Skripsi Fakultas Ekonomi dan Ilmu Sosial UIN Sultan Syarif Kasim Riau.

Arianto, Taufik. 2004. Profil Persaingan Usaha Dalam Industri Perbankan Indonesia. Perbanas Finance \& Banking Journal, Vol. 6, No. 2, P. 95-108.

Dendawijaya, Lukman. 2009. Manajemen Perbankan. Ghalia Indonesia. Jakarta.

Djohanputro, Bramantyo. 2006. PrinsipPrinsip Ekonomi Makro.Cet.I. Penerbit PPM. Jakarta.

Ghozali, Imam. 2013. Aplikasi Analisis Multivariate dengan Program SPSS, edisi ketujuh. Universitas Diponegoro. Semarang.

Nadhiroh, Ulfatun. 2016. Pengaruh Nilai Tukar (IDR/USD), Harga Minyak Dunia, Harga Emas Dunia, Tingkat Inflasi dan Dow Jones Industrial Average (DJIA) terhadap Indeks Harga Saham Gabungan (IHSG) di Bursa Efek Indonesia (BEI) Periode Januari 2008 - Februari 2016). Skripsi Fakultas Ekonomi dan Ilmu Sosial, UIN Suska Riau.

Rahardja, P. \& Manurung, M. 2008 Pengantar Ilmu Ekenomi: Mikro Ekonomi dan Makro Ekonomi Jilid 2. Fakultas Ekonomi Universitas Indonesia. Jakarta.

Sahara, Ayu Yanita. 2013. Analisis Pengaruh Inflasi, Suku Bunga BI, dan Produk Domestik Bruto terhadap Return on Asset (ROA) Bank Syariah Indonesia. Jurnal Ilmu Manajemen (JIM). Vol. 1, No. 1. 